\title{
ANALISIS SWOT WILAYAH TERDAMPAK ERUPSI GUNUNG AGUNG PADA MASYARAKAT DI KECAMATAN KUBU TAHUN 2018
}

\author{
Ni Komang Ary Sugiantari'1, I Nyoman Sujana², Kadek Rai Suwena ${ }^{3}$ \\ Program Studi Pendidikan Ekonomi \\ Universitas Pendidikan Ganesha \\ Singaraja, Indonesia \\ e-mail: arysugiantari96@gmail.com¹, \\ nyoman.sujana@undiksha.ac.id ${ }^{2}$, kadek suwena@yahoo.co.id ${ }^{3}$
}

\begin{abstract}
Abstrak
Penelitian ini bertujuan untuk mengetahui kekuatan, kelemahan, peluang, ancaman dan strategi yang tepat untuk diterapkan Wilayah terdampak erupsi Gunung Agung pada masyarakat di Kecamatan Kubu. Jenis penelitian yang digunakan dalam penelitian ini adalah penelitian deskriptif. Pengumpulan data menggunakan metode wawancara dan observasi. Analisis data yang digunakan dalam penelitian ini adalah analisis SWOT. Hasil penelitian ini menunjukkan bahwa, kekuatan yang dimiliki perusahaan pertambangan Galian C adalah pasir super yang paling diminati para pelanggan, tempat yang strategis, cara memasarkannya melalui marketing, memiliki beberapa peralatan canggih, keuntungan yang diperoleh dipergunakan untuk biaya operasional. Kelemahan pada perusahaan pertambangan Galian C adalah hanya dipasarkan di wilayah pulau Bali, pada saat pengerukan pasir yang didapat tidak terlalu bagus terkadang yang keluar pasirnya agak merah. Peluang pada perusahaan pertambangan Galian C adalah dilakukan upaya penghijauan supaya lahan bisa produktif lagi, kemajuan teknologi saat ini sangat memberikan dampak positif. Ancaman pada perusahaan pertambangan Galian $\mathrm{C}$ adalah jika harga bahan bakar minyak (BBM) meningkat maka biaya operasional akan meningkat, memiliki beberapa pesaing utama. Strategi yang tepat untuk diterapkan sebagai strategi pengembangan pertambangan Galian C adalah strategi penetrasi pasar.
\end{abstract}

Kata kunci: kekuatan, kelemahan, peluang, ancaman

\begin{abstract}
This study aims to determine the strengths, weaknesses, opportunities, threats and the right strategy to be applied to the area affected by the Mount Agung Eruption to the people in Kubu District. The type of research used in the research is descriptive research. Data collection methods use interview and observation methods. The data analysis used in this study is SWOT analysis. This research shows that, the strength of the Galian C mining company is the super sand that is most in demand by customers, a strategic place, how to market it through marketing, have some sophisticated equipment, the profits earned are used for operational costs. The weakness in the Galian C mining company is that it is only marketed on the island of Bali, when the sand dredging is not too good, sometimes the sand is rather red. The opportunity for the Galian C mining company is to make efforts to reforest so that the land can be productive again, current technological advances have had a very positive impact. The threat to the Galian C mining company is that if the price of fuel (BBM) increases, the operational costs will increase, have a few main competitors. The right strategy to implement as a strategy for developing Galian C mining is a market penetration strategy.
\end{abstract}

Keywords : strengths, weaknesses, opportunities, threats 


\section{PENDAHULUAN}

Salah satu gunung yang terkenal di Bali adalah Gunung Agung. Gunung ini tentu memiliki peranan yang sangat sentral bagi kehidupan masyarakat Bali, khususnya bagi masyarakat di Kabupaten Karangasem. Selain terkenalnya Gunung Agung, Bali juga terkenal akan keindahan pulau dengan julukan pulau seribu pura, banyak wisatawan baik wisatawan luar negeri atau wisatawan lokal yang berkunjung ke Bali, disamping itu Bali juga memiliki potensi bahan galian $\mathrm{C}$ yang banyak terdapat di wilayah-wilayah yang ada di Bali yang dihasilkan dari proses erupsi Gunung Berapi. Adanya bahan galian $C$ ini sangat bermanfaat bagi kehidupan manusia karena bahan galian $\mathrm{C}$ bisa dimanfaatkan untuk bahan bangunan.

Kabupaten Karangasem adalah salah satu Kabupaten di Bali yang memiliki potensi bahan galian $\mathrm{C}$. Pengembangan pertambangan yang ada di Kabupaten Karangasem secara tidak langsung ini dapat memberikan lapangan pekerjaan bagi masyarakat dan dapat mengurangi pengangguran, banyak daerah yang ada di Kabupaten Karangasem menjadi tempat penambangan yang berskala kecil maupun besar. Untuk memenuhi kebutuhan hidupnya manusia mengambil sumber daya alam yang tersimpan atau terkandung dalam bumi. Oleh karena itu, manusia melakukan kegiatan usaha penambangan dengan mengeksploitasi lahan yang ada disekitarnya. Menurut Sukandarrumidi (2017) teknik penambangan dilakukan dengan tambang terbuka dalam bentuk kuari tipe sisi bukit (side hill type). Untuk penambangan skala besar pembongkaran dibantu dengan sistem peledakan beruntun dibantu peralatan berat antara lain escavator dan ripper, sedangkan untuk penambangan skala kecil dilakukan dengan alat sederhana antara lain cangkul, ganco dan sekop. Apabila skala penambangannya kecil, sistem yang diterapkan dalam kegiatan penambangan adalah sistem gophering, mengikuti bagian/jalur batu gamping yang relatif mudah dibongkar. Menurut Samanlangi (2016) persiapan pembukaan tambang bawah tanah adalah semua pekerjaan dalam rangka penyiapan atau pembangunan fasilitas kerja untuk kelancaran produksi tambang bawah tanah. Pekerjaan ini dibagi menjadi dua bagian yaitu: pembangunan fasilitas permukaan (surface facilities), pembangunan fasilitas bawah tanah (underground facilities). Sebelum adanya tambang galian $\mathrm{C}$, adapun dampak yang dihasilkan dari erupsi Gunung Berapi. Baik itu dampak positif maupun dampak negatif. Dampak negatif antara lain: mencemari lingkungan misalnya ketika gunung api mengalami erupsi akan mengeluarkan berbagai macam material baik padat, cair, maupun gas. Ketika material-material ini keluar maka akan menimbulkan pencemaran pada lingkungan, merusak lingkungan, tidak hanya mencemari saja bahkan lebih parah lagi material-material Gunung Agung dapat merusak lingkungan. Lingkungan yang rusak disebabkan oleh dorongan tenaga dari material-material yang keluar dari kawah gunung tersebut, mencemari udara, dimana Gunung Berapi mengeluarkan abu vulkanik yang akan berdampak bagi manusia dan makhluk hidup lainnya, merugikan rakyat Bali, semua setuju bahwa bencana alam dapat menyebabkan penderitaan rakyat. Banyak rakyat yang mengalami kerugian, kerugian material atau spiritual. Dampak positif antara lain: abu vulkanik ini bisa membuat tanah di Bali subur terlebih tanah yang berada dilereng gunung maka dari itu tidak heran jika disekitar gunung banyak menemukan tanaman-tanaman yang tumbuh subur, menambah persediaan bahan bangunan, berbagai bahan bangunan akan kita panen pasca Gunung Berapi meletus. Beberapa bahan bangunan tersebut antara lain adalah pasir, kerikil dan jenis-jenis batuan penyusun lapisan bumi.

Masyarakat di wilayah terdampak erupsi Gunung Agung adalah masyarakat yang tinggal disekitaran galian C. Kecamatan Kubu Kabupaten Karangasem merupakan salah satu lokasi penambangan bahan galian $C$ yang merupakan proyek penambangan pasir dan batu. Dalam observasi awal melalui pengamatan dan wawancara yang peneliti 
lakukan terhadap masyarakat disekitaran galian C mengenai analisis SWOT. Analisis SWOT berkaitan dengan lingkungan internal dan eksternal.

Lingkungan internal dan eksternal adalah lingkungan dalam maupun luar perusahaan. Menurut Rangkuti (2017) lingkungan internal ialah kondisi riil di dalam suatu organisasi (perusahaan) yang relatif mudah dikelola. Analisis internal merupakan proses para perencana strategi mengkaji faktor internal perusahaan untuk menentukan dimana perusahaan memiliki kekuatan dan kelemahan yang berarti sehingga perusahaan dapat memanfaatkan peluang dengan cara yang paling efektif dan dapat menghadapi ancaman didalam lingkungan. Dari beberapa pendapat tersebut, maka dapat disimpulkan bahwa analisis lingkungan internal adalah uraian tentang para perencana strategi untuk menentukan dimana perusahaan memiliki kekuatan dan kelemahan. Menurut Rangkuti (2017) analisis lingkungan internal yang dianalisis sebagai berikut: pemasaran, produksi atau operasi, sumber daya manusia, keuangan. Menurut Rangkuti (2017) analisis lingkungan eksternal yang dianalisis terdiri dari politik dan hukum, ekonomi, sosial budaya, teknologi, persaingan, pemasok". Berdasarkan beberapa pendapat tersebut, maka dapat disimpulkan bahwa faktor eksternal terdiri dari faktor politik dan hukum, ekonomi, sosial budaya, teknologi, persaingan, pemasok. Berpedoman penjelasan dari Rangkuti (2006) berkaitan dengan SWOT, ditemukan data yang berkaitan dengan variabel kekuatan (strengths), masyarakat di wilayah terdampak erupsi Gunung Agung adalah masyarakat yang berada disekitar penambangan bahan galian $\mathrm{C}$ yang merupakan proyek pasir dan batu, adanya pasir dan batu tersebut adalah akibat dari adanya erupsi Gunung Agung yang setelah beberapa tahun kemudian akan menjadi penghasilan bagi masyarakat sekitar dan akan ada pemasukan di Desa. Pada variabel kelemahan (weaknesses), masyarakat sekitar yang dekat dengan galian C juga merasakan adanya kebisingan akibat aktivitas yang terjadi di galian, selain itu pada saat banyaknya truk pengangkut pasir yang berdatangan yang akan mengambil pasir atau batu maka akan terjadi kemacetan, hal tersebut juga merupakan kelemahan pada galian C. Variabel peluang (opportunities), adanya perekrutan tenaga kerja. Karyawan yang bekerja pada galian $\mathrm{C}$ tersebut adalah masyarakat yang berada disekitar galian $\mathrm{C}$ dan hal tersebut akan membantu perekonomian masyarakat sekitar. Ancaman (threats), misalnya penggalian pasir yang secara terus-menerus sehingga jika terjadi erupsi Gunung Agung yang cukup besar dan mengeluarkan lava panas maupun lava dingin yang mengaliri galian C dan arus tersebut tidak kuat menampung aliran lava maka akan berakibat pada masyarakat yang tinggal di sekitar galian $\mathrm{C}$ karena aliran lava tersebut mungkin saja akan mengaliri pemukiman warga disekitaran Galian C.

Berdasarkan latar belakang permasalahan di atas, maka penulis tertarik untuk melakukan penelitian dengan judul Analisis SWOT Wilayah Terdampak Erupsi Gunung Agung pada Masyarakat di Kecamatan Kubu Tahun 2018.

\section{METODE}

Penelitian ini merupakan penelitian deskriptif. Menurut Narbuko (2010) penelitian deskriptif merupakan penelitian yang berusaha untuk menuturkan pemecahan masalah yang ada sekarang berdasarkan data. Menurut Ghony (2012) pendekatan kualitatif adalah penelitian yang menghasilkan penemuan-penemuan yang tidak dapat dicapai dengan menggunakan prosedur statistik.

Penelitian ini dilakukan dengan menganalisis lingkungan internal dan eksternal wilayah terdampak erupsi Gunung Agung pada masyarakat di Kecamatan Kubu. Melalui analisis lingkungan internal dan lingkungan eksternal akan diketahui strategi yang dapat diterapkan pada wilayah terdampak erupsi tersebut. Dengan menganalisis lingkungan internal akan diketahui kekuatan dan kelemahan, sedangkan dengan menganalisis lingkungan eksternal akan diketahui peluang dan ancaman 
yang dihadapi wilayah terdampak erupsi Gunung Agung. Adapun lingkungan internal dalam penelitian ini yaitu, pemasaran, produksi atau operasi, sumber daya manusia, keuangan. Lingkungan eksternal dalam penelitian ini yaitu, politik, ekonomi, sosial budaya, teknologi, pesaing dan pemasok. Setelah diketahui kekuatan, kelemahan, peluang dan ancaman, maka dapat ditentukan strategi yang dapat untuk diterapkan wilayah terdampak erupsi Gunung Agung pada masyarakat di Kecamatan Kubu.

Subjek penelitian ini adalah masyarakat yang tinggal di sekitaran galian C yang kemungkinan terkena dampak dari adanya erupsi Gunung Agung di Kecamatan Kubu, Kabupaten Karangasem. Objek dari penelitian ini adalah analisis SWOT yaitu, kekuatan (strengths), kelemahan (weakness), peluang (opportunities) dan ancaman (threats). Adapun jumlah subjek yang akan dijadikan sampel dalam penelitian ini nampak pada tabel 1 .

Tabel 1. Data Jumlah Subjek Sampel Penelitian

\begin{tabular}{lllr}
\hline No. & Desa & $\begin{array}{l}\text { Jumlah } \\
\text { atau } \\
\text { (Orang) }\end{array}$ & $\begin{array}{r}\text { Pengelola } \\
\text { Masyarakat }\end{array}$ \\
\hline 1 & Sukadana & 13 \\
2 & Baturinggit & 7 \\
3 & Tulamben & 10 \\
\hline Total & & 30 \\
\hline
\end{tabular}

Sumber data: Survei Peneliti, 2018

Metode pengumpulan data yang digunakan dalam penelitian ini adalah metode observasi merupakan prosedur yang sistematis dan standar dalam pengumpulan data. Peneliti tidak hanya berkomunikasi dengan orang tetapi juga melibatkan proses pengamatan dan ingatan (Sumarni, 2006).

Wawancara adalah pengumpulan data dengan mengajukan pertanyaan langsung kepada responden untuk memperoleh informasi verbal dari responden (Wijaya, 2013). Jenis wawancara yang digunakan dalam penelitian ini adalah wawancara terstruktur. Narasumber dalam wawancara ini adalah pengelola galian C. Pertanyaan yang diajukan berupa indikator dari lingkungan internal dan eksternal yang menjadi kekuatan, kelemahan, peluang dan ancaman yang dimiliki wilayah terdampak erupsi Gunung Agung.

Analisis data dalam penelitian ini adalah analisis deskriptif kualitatif. Menurut Moleong (2007) metodelogi kualitatif merupakan prosedur penelitian yang menghasilkan data deskriptif berupa kata-kata tulisan maupun lisan dari orangorang dan perilaku yang diamati. Menurut Ghony (2012) penelitian kualitatif adalah penelitian yang menghasilkan penemuanpenemuan yang tidak dapat dicapai dengan menggunakan prosedur statistik atau dengan cara-cara kuantifikasi. Dalam penelitian ini menggunakan teknik analisis kekuatan, kelemahan, peluang dan ancaman (SWOT Analysis) yang digunakan untuk mengidentifikasi lingkungan internal dan eksternal.

Setelah analisis internal dan eksternal, selanjutnya dilakukan perumusan strategi yang tepat dengan mempertimbangkan di kuadran mana suatu perusahaan yang dikaji berada. Setelah mendapatkan gambaran tersebut, perusahaan sebaiknya menetapkan strateginya sesuai dengan posisi pada kuadrannya, yaitu kuadran pertama adalah strategi pertumbuhan agresif, sedangkan pada kuadran kedua adalah strategi diversifikasi, dan untuk kuadran ketiga adalah strategi putar haluan, serta pada kuadran keempat adalah strategi bertahan atau difensif (Assauri, 2013). Cara untuk menentukan posisi titik kuadran sebuah perusahaan berada menurut Marimin (2004) dapat menggunakan rumusan sebai berikut. Total skor faktor kekuatan-kelemahan Total skor faktor peluang-ancaman.

Dengan rumus tersebut, akan diketahui posisi kuadran dari sebuah perusahaan. Setelah posisi dari kuadran tersebut diketahui maka dapat ditentukan strategi yang tepat unuk diterapkan.

\section{HASIL DAN PEMBAHASAN Hasil Penelitian}

Berdasarkan hasil penelitian mengenai analisis SWOT adalah kekuatan wilayah terdampak Erupsi Gunung Agung 
pada Masyarakat di Kecamatan Kubu. Pemasaran di pertambangan Galian C menjual berbagai jenis material, material yang paling diminati yaitu pasir super. Cara memasarkan produknya, yaitu melalui marketing, membuat brosur, kerjasama dengan pabrik-pabrik beton, menghubungi supir-supir truk dan ada juga yang langsung datang sendiri. Di samping itu tempatnya juga strategis. Bagi supir-supir truk yang langsung datang sendiri ke Galian juga disediakan tempat untuk beristirahat.

Dalam proses produksi berdasarkan hasil wawancara pada penambang Galian C ada beberapa peralatan yang masih layak untuk digunakan. Sudah mempunyai peralatan canggih yang bernama crusher, crusher tersebut adalah alat yang digunakan untuk memproduksi batu besar menjadi 6 jenis bagian, jika ada peralatan yang rusak akan langsung diperbaiki oleh pegawai mekanik. Penempatan dan pembagian kerja sumber daya manusia yang ada di perusahaan pertambangan Galian C adalah sebagai berikut: kasir, pengawas, operator, tukang crusher, mekanik, keamanan, dan supir. Apresiasi perusahaan terhadap sumber daya manusia seperti karyawan dengan memberikan Tunjangan Hari Raya (THR) dan pembagian sembako setiap 6 bulan sekali secara keseluruhan. Berdasarkan hasil wawancara, perusahaan pertambangan Galian C hanya menyusun laporan keuangan mengenai penjualan dan pengeluaran. Pada perusahaan pertambangan Galian C, keuntungan yang diperoleh dalam sebulan sekitar Rp.10.000.000-Rp.20.000.000, dan keuntungan yang diperoleh dipergunakan untuk biaya operasional.

Kelemahan wilayah terdampak Erupsi Gunung Agung pada Masyarakat di Kecamatan Kubu adalah pemasaran berbagai jenis material pertambangan di Galian C hanya dipasarkan di beberapa kabupaten di wilayah pulau Bali. Dalam proses produksi tidak selamanya pada saat pengerukan pasir, pasir yang di dapat akan bagus namun terkadang saat tebingnya dikeruk yang keluar pasirnya agak merah karena jarak 1 meter sudah berbeda lapisan tanah.
Peluang Wilayah Terdampak Erupsi Gunung Agung pada Masyarakat di Kecamatan Kubu adalah kebijakan pemerintah jika terjadi kerusakan lingkungan akibat Galian C yaitu dengan melakukan penghijauan supaya lahan bisa produktif lagi. Perusahaan pertambangan Galian C tersebut juga sudah memiliki surat izin dari pemerintah dalam menjalankan usahanya. Perusahaan pertambangan Galian C ini juga ada pemungutan pajak pemerintahnya. Dalam proses produksi yang terjadi di pertambangan Galian C tidak akan mengganggu masyarakat sekitar karena jauh dari pemukiman warga, meskipun ada beberapa masyarakat yang merasa terganggu, masyarakat tersebut akan diberikan yang namanya uang bising. Pengaruh kemajuan teknologi saat ini sangat memberikan dampak positif bagi proses pertambangan Galian C, contohnya yang dulunya pemecah batu dilakukan secara manual sekarang sudah memakai mesin crusher, komunikasi dengan relasi-relasi lebih gampang.

Ancaman Wilayah Terdampak Erupsi Gunung Agung pada Masyarakat di Kecamatan Kubu adalah faktor ekonomi yang berpengaruh terhadap biaya operasional, misalnya jika harga Bahan Bakar Minyak (BBM) meningkat maka biaya operasional akan meningkat. Setiap perusahaan pastinya memiliki pesaing dalam berwirausaha begitupun halnya dengan peurusahaan pertambangan Galian C ada beberapa yang menjadi pesaing utama. Pada perusahaan pertambangan Galian C ada beberapa distributor yang dimiliki yaitu sekitar 25 truk per hari sangat sedikit dibandingkan tahun-tahun sebelumnya. Dan untuk saat ini belum ada peningkatan permintaan produk dikarenakan kondisi saat ini sedang sepi.

Strategi yang tepat untuk diterapkan Wilayah Terdampak Erupsi Gunung Agung pada Masyarakat di Kecamatan Kubu adalah Matriks Internal Strategic Faktor Analysis Summary (IFAS) yang menggambarkan kekuatan dan kelemahan wilayah terdampak erupsi Gunung Agung pada masyarakat di Kecamatan Kubu nampak pada tabel 2. 
Tabel 2. Hasil Wawancara Terkait Kekuatan dan Kelemahan dalam Perusahaan Galian C

\section{Faktor Strategi Internal}

Kekuatan

1. Dari berbagai jenis material yang dipasarkan, material yang paling diminati yaitu pasir super. Tempatnya strategis dibandingkan dengan Galian C lain.

2. Melalui marketing, membuat brosur, kerjasama dengan pabrik-pabrik beton, menghubungi supir-supir truk dan ada juga yang langsung datang sendiri.

3. Beberapa peralatan masih layak untuk digunakan, mempunyai peralatan canggih yang bernama crusher, jika ada peralatan yang rusak akan langsung diperb aiki oleh pegawai mekanik.

4. Kasir, pengawas, operator, tukang crusher, mekanik, keamanan, dan supir.

5. Dengan memberikan dan pembagian sembako setiap 6 bulan sekali secara keseluruhan, sudah banyak memiliki karyawan tetap, jika dibandingkan dengan perusahaan Galian C lainnya

6. Hanya menyusun laporan keuangan mengenai penjualan dan pengeluaran.

7. Keuntungan yang diperoleh dalam sebulan

Rp.10.000.000,00Rp.20.000.000,00.

8. Keuntungan yang diperoleh dipergunakan untuk biaya operasinal.

Kelemahan

1. Berbagai jenis material Galian $\mathrm{C}$ hanya dipasarkan di wilayah pulau Bali

2. Pasir yang di dapat tidak selalu bagus namun terkadang saat tebingnya dikeruk yang keluar pasirnya agak merah, karena jarak 1 meter sudah

\section{Bobot Rating Skor}

Komentar

$0,15 \quad 4$

$4 \quad 0,60$

0,60 Pasir super yang paling diminati para pelanggan

$0,10 \quad 2$

2

0,20 Cara memasarkan bisa melalui media elektronik selain supir datang langsung

$0,15 \quad 2$

2

0,30 Sudah memakai peralatan yang canggih dan memadai

0,20 Memiliki banyak karyawan dan pembagian tugasnya masing-masing

0,10

3

0,30 Pemberian reward kepada karyawan dan sudah memiliki karyawan tetap
$0,1020,20$ Melakukan penyusunan laporan keuangan

$0,1020,20$ Keuntungan yang diperoleh tidak menentu

$0,10 \quad 2$

0,20 Keuntungan dipergunakan untuk biaya operasional

0,05

1

0,05 Belum sampai keluar pulau Bali

0,05 Pasir yang didapatkan tidak selalu bagus 


\author{
Matriks Eksternal Strategic Faktor \\ Analysis Summary (EFAS) yang \\ menggambarkan peluang dan Ancaman
}

wilayah terdampak erupsi Gunung Agung pada masyarakat di Kecamatan Kubu nampak pada tabel

Tabel 3. Hasil Wawancara Terkait Peluang dan Ancaman dalam Perusahaan Galian C

\section{Faktor Strategi Eksternal}

\section{Peluang}

1. Reklamasi setelah penggalian atau pengerukan contohnya, sudah melakukan penghijauan supaya lahan bisa produktif lagi. C tersebut juga sudah memiliki surat izin.

3. Perusahaan pertambangan Galian $C$ ini juga ada pemungutan pajak pemerintahnya.

4. Tidak akan mengganggu masyarakat sekitar karena jauh dari pemukiman warga. Meskipun ada beberapa masyarakat yang merasa terganggu, masyarakat tersebut akan diberikan yang namanya uang bising.

5. Sangat memberikan dampak positif bagi proses pertambangan Galian C, contohnya dulu pemecah batu dilakukan secara manual sekarang sudah memakai mesin crusher, komunikasi dengan relasi-relasi lebih gampang.

Ancaman

1. Jika harga Bahan Bakar Minyak (BBM) meningkat maka biaya operasional akan meningkat, jika harga Bahan Bakar Minyak (BBM) meningkat harga material menurun maka akan mengalami kerugian.

2. Ada beberapa yang menjadi pesaing utama. Namun setiap perusahaan memiliki cara tertentu untuk menarik minat pembelinya dan perusahaan akan mengutamakan kualitas, mutu dan pelayanan.

3. Ada beberapa distributor yang dimiliki yaitu sekitar 25 truk per hari sangat sedikit dibandingkan tahuntahun sebelumnya.

4. Untuk saat ini belum ada peningkatan permintaan produk dikarenakan kondisi saat ini sedang sepi. Bobot Rating Skor

\section{Komentar}

0,15

4

0,60

Sudah melakukan penghijauan

$0,10 \quad 3$

0,30

Memiliki surat izin usaha

0,10

0,20 Melakukan

pembayaran pajak

$0,10 \quad 3$

0,30 Jika masyarakat terganggu dengan pertambangan Galian C maka akan diberikan yang namanya uang bising

$0,1540,60 \quad \begin{aligned} & \text { Kemajuan teknologi } \\ & \text { sangat memberikan } \\ & \text { dampak positif }\end{aligned}$

$\begin{array}{llll}0,10 & 2 & 0,20 & \text { Sangat berpengaruh }\end{array}$ terhadap biaya operasional jika harga BBM meningkat

$0,1520,30 \quad \begin{aligned} & \text { Setiap perusahaan } \\ & \text { memiliki cara tertentu } \\ & \text { untuk menghadapi } \\ & \text { para pesaingnya }\end{aligned}$

0,05 Belum mempunyai banyak distributor

\begin{tabular}{lllr}
0,1022 & 0,20 & $\begin{array}{l}\text { Tidak } \\
\text { peningkatan } \\
\text { permintaan } \\
\text { untuk saat ini }\end{array}$ & produk \\
\hline 1,00 & 2,75 & \\
\hline
\end{tabular}


Berdasarkan hasil dari analisis IFAS diperoleh mengenai total skor tentang kekuatan wilayah yang terdampak Erupsi Gunung Agung pada masyarakat di Kecamatan Kubu sebesar 2,20. Sedangkan mengenai total skor tentang kelemahan wilayah yang terdampak Erupsi Gunung Agung pada masyarakat di Kecamatan Kubu sebesar 0,10. Jadi jumlah skor pada faktor kekuatan yaitu sebesar 2,20 dikurangi jumlah skor faktor kelemahan sebesar 0,10 adalah 2,10. Berdasarkan hasil tersebut maka, titik kuadran faktor internal berada pada titik 2,10.

Berdasarkan hasil dari analisis EFAS diperoleh skor peluang wilayah terdampak Erupsi Gunung Agung pada masyarakat di Kecamatan Kubu adalah yaitu sebesar 2,00 . Sedangkan total skor ancaman wilayah yang terdampak Erupsi Gunung Agung pada masyarakat di Kecamatan Kubu sebesar 0,75. Jadi jumlah skor peluang sebesar 2,00 dikurangi jumlah skor faktor ancaman sebesar 0,75 adalah 1,25. Jadi berdasarkan hasil tersebut maka titik kuadran faktor ekternal adalah pada titik 1,25.

Berdasarkan kedua hasil perhitungan tersebut diperoleh hasil IFAS yaitu berada pada titik 2,10 dan EFAS berada pada titik 1,25. Ini berarti bahwa matriks strategi SWOT wilayah yang terdampak Erupsi Gunung Agung pada masyarakat di Kecamatan Kubu berada pada titik $(2,10 ; 1,25)$. Berdasarkan hasil tersebut, maka strategi yang tepat untuk diterapkan wilayah terdampak Erupsi Gunung Agung pada masyarakat di Kecamatan Kubu dapat dilihat pada gambar 1.

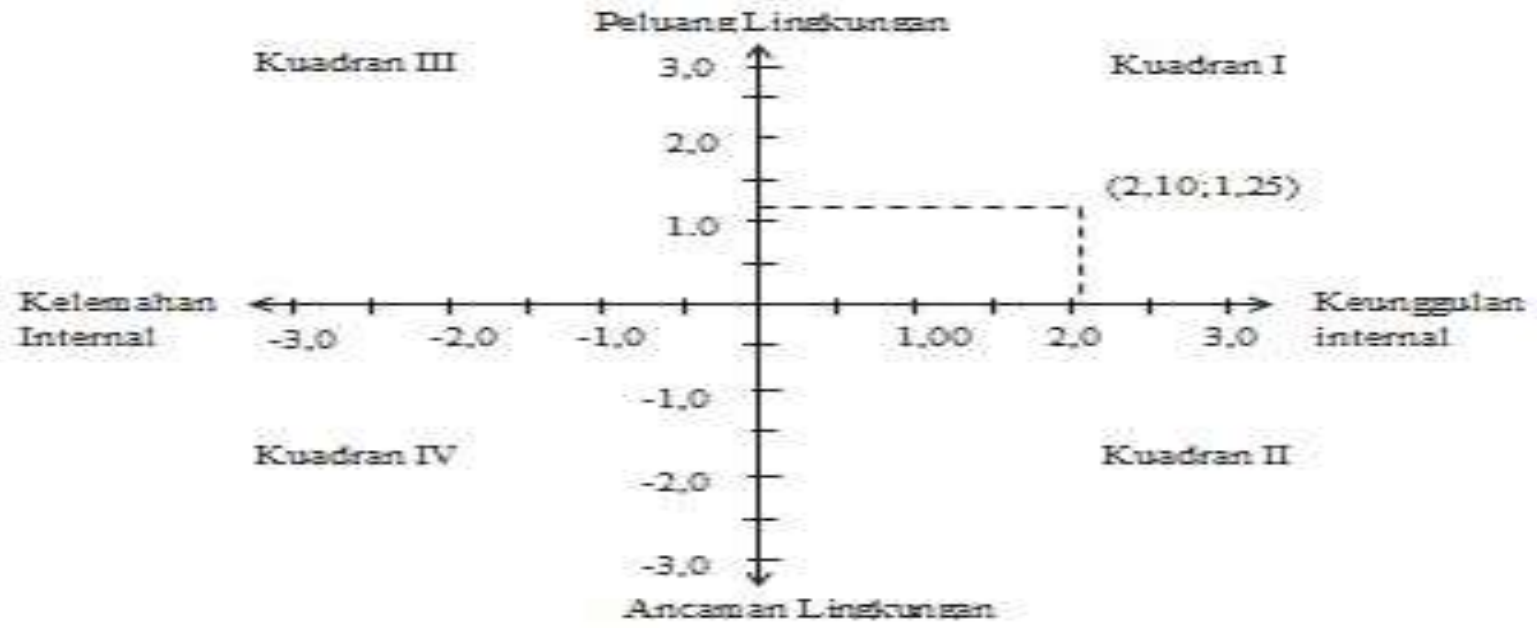

Gambar 1. Matriks Strategi SWOT

Berdasarkan gambar 1. tersebut dapat dilihat bahwa posisi wilayah terdampak Erupsi Gunung Agung pada masyarakat di Kecamatan Kubu berada pada kuadran I. Ini berarti bahwa strategi yang tepat diterapkan wilayah terdampak Erupsi Gunung Agung pada masyarakat di Kecamatan Kubu adalah strategi pertumbuhan agresif. Salah satu strategi pertumbuhan agresif yang disarankan yaitu strategi penetrasi pasar.

\section{Pembahasan}

Kekuatan Wilayah Terdampak Erupsi Gunung Agung pada Masyarakat di Kecamatan Kubu adalah pemasaran di pertambangan Galian C menjual berbagai jenis material yang dipasarkan, material yang paling diminati para pelanggan penambang Galian C yaitu pasir super yang diberi bobot 0,15 , pada perusahaan penambangan Galian $\mathrm{C}$ juga memiliki cara tertentu dalam memasarkan produknya, yaitu melalui marketing, membuat brosur, kerjasama dengan pabrik-pabrik beton, menghubungi supir-supir truk dan ada juga yang langsung datang sendiri yang diberi bobot 0,10 . Sehingga pemasaran pada perusahaan pertambangan Galian C merupakan kekuatan perusahaan yang akan menimbulkan keinginan para pembeli untuk datang dan membeli material tersebut. Dalam proses produksi juga menerapkan sistem mekanik juga diterapkan dalam Galian C ini, jika ada peralatan yang rusak akan langsung 
diperbaiki oleh pegawai mekanik, dimana bobot ini diberi 0,15. Produksi/Operasi ini menjadi kekuatan bagi perusahaan pertambangan Galian C.

Penempatan dan pembagian kerja sumber daya manusia yang ada di perusahaan pertambangan Galian C adalah sebagai berikut: kasir, pengawas, operator, tukang crusher, mekanik, keamanan, dan supir yang diberi bobot 0,10 , apresiasi perusahaan terhadap sumber daya manusia seperti karyawan dengan memberikan Tunjangan Hari Raya (THR) dan pembagian sembako setiap 6 bulan sekali secara keseluruhan yang diberi bobot 0,10. Hal ini merupakan kekuatan bagi perusahaan pertambangan Galian C. Perusahaan pertambangan Galian C hanya menyusun laporan keuangan mengenai penjualan dan pengeluaran yang diberi bobot 0,10 , pada perusahaan pertambangan Galian $C$, keuntungan yang diperoleh dalam sebulan sekitar Rp.10.000.000-Rp.20.000.000 yang diberi bobot 0,10 dan keuntungan yang diperoleh dipergunakan untuk biaya operasional yang diberi bobot 0,10, sehingga hal ini merupakan kekuatan bagi perusahaan pertambangan Galian C.

Kelemahan Wilayah Terdampak Erupsi Gunung Agung pada Masyarakat di Kecamatan Kubu adalah pemasaran berbagai jenis material pertambangan di Galian C hanya dipasarkan di beberapa kabupaten di wilayah pulau Bali belum sampai keluar pulau Bali. Berdasarkan observasi yang dilakukan oleh peneliti maka nilai atau bobot untuk indkator ini adalah 0,05 . Dalam proses produksi tidak selamanya pada saat pengerukan pasir, pasir yang di dapat akan bagus dan sesuai yang diharapkan namun terkadang saat tebingnya dikeruk yang keluar pasirnya agak merah, jarak 1 meter sudah berbeda lapisan tanah. Hal ini diberi bobot 0,05 karena menjadi kelemahan bagi perusahaan pertambangan Galian C.

Peluang Wilayah Terdampak Erupsi Gunung Agung pada Masyarakat di Kecamatan Kubu adalah kebijakan pemerintah jika terjadi kerusakan lingkungan akibat Galian C yaitu dengan reklamasi setelah penggalian atau pengerukan contohnya, sudah melakukan penghijauan supaya lahan bisa produktif lagi yang diberi bobot 0,15 . Perusahaan pertambangan Galian C tersebut juga sudah memiliki surat izin dari pemerintah dalam menjalankan usahanya yang diberi bobot 0,10 , sehingga hal tersebut menjadi peluang bagi perusahaan pertambangan Galian C. Ekonomi merupakan salah satu ilmu sosial yang mempelajari aktivitas manusia yang berhubungan dengan produksi, distribusi dan konsumsi terhadap barang dan jasa. Perusahaan pertambangan Galian C ini juga ada pemungutan pajak pemerintahnya yang diberi bobot 0,10 karena pembayaran pajak wajib dilakukan dalam setiap perusahaan.

Dalam proses produksi yang terjadi di pertambangan Galian C tidak akan mengganggu masyarakat sekitar karena jauh dari pemukiman warga, disamping itu di wilayah kecamatan kubu sudah ditetapkan oleh pemerintah sebagai daerah pertambangan Galian C. Meskipun ada beberapa masyarakat yang merasa terganggu, masyarakat tersebut akan diberikan yang namanya uang bising. Hal tersebut diberi bobot 0,10 karena izin dari masyarakat setempat sangat berarti bagi setiap perusahaan yang akan mendirikan usaha di wilayah manapun.

Pengaruh kemajuan teknologi saat ini sangat memberikan dampak positif bagi proses pertambangan Galian C, contohnya yang dulunya pemecah batu dilakukan secara manual sekarang sudah memakai mesin crusher, komunikasi dengan relasi-relasi lebih gampang. Indikator perkembangan teknologi informasi diberi bobot 0,15 karena indikator ini sangat penting untuk memudahkan dalam proses pengerjaan di pertambangan Galian C serta sangat mudah untuk memberikan informasi ke pihak yang bersangkutan. Faktor ekonomi yang berpengaruh terhadap biaya operasional. Hal ini menjadi ancaman dalam menjalankan usaha pertambangan Galian C karena jika harga Bahan Bakar Minyak (BBM) mengalami kenaikan maka akan sangat berpengaruh terhadap biaya operasional, sehingga indikator ini diberi bobot 0,10 . Setiap perusahaan pastinya memiliki pesaing dalam berwirausaha 
begitupun halnya dengan peurusahaan pertambangan Galian C ada beberapa yang menjadi pesaing utama. Indikator ini diberi bobot 0,15 karena adanya pesaing dalam setiap perusahaan sangat penting untuk diperhatikan.

Pada perusahaan pertambangan Galian C ada beberapa distributor yang dimiliki yaitu sekitar 25 truk per hari sangat sedikit dibandingkan tahun-tahun sebelumnya yang diberi bobot 0,05. Dan untuk saat ini belum ada peningkatan permintaan produk dikarenakan kondisi saat ini sedang sepi yang diberi bobot 0,10 , sehingga hal tersebut akan menjadi ancaman bagi perusahaan pertambangan Galian C.

Strategi yang tepat untuk diterapkan terletak di kuadran I, maka strategi yang tepat untuk diterapkan sebagai strategi wilayah terdampak Erupsi Gunung Agung pada masyarakat di Kecamatan Kubu adalah strategi pertumbuhan agresif. Ini merupakan situasi yang sangat menguntungkan. Perusahaan tersebut memiliki peluang dan kekuatan sehingga dapat memanfaatkan peluang yang ada. Strategi yang harus diterapkan dalam kondisi ini adalah mendukung kebijakan pertumbuhan yang agresif (growth oriented strategi). Salah satu strategi pertumbuhan agresif yang disarankan adalah strategi penetrasi pasar. Strategi penetrasi pasar merupakan strategi peningkatan market share atau pangsa pasar untuk produk yang ada melalui upaya-upaya pemasaran yang lebih intensif dan optimal.

Hasil penelitian ini sesuai dengan teorinya Sunarto (2007) yang menyatakan bahwa teori yang dapat digunakan dalam pertumbuhan pasar adalah strategi panetrasi pasar. Panetrasi pasar adalah strategi yang memusatkan pada pertumbuhan pasar yang kini dimasuki oleh perusahaan melalui usaha-usaha pemasaran yang lebih agresif untuk menjual produk-produk yang kini dihasilkannya. Strategi ini dapat dilakukan melalui observasi dan wawancara yang dilakukan peneliti kepada karyawan dan owner pada perusahaan Galian C. Strategi panetrasi pasar juga dapat dilakukan dengan memasang iklan pada media cetak, elektronik maupun internet dan publisitas.

Hasil penelitian ini juga didukung dengan hasil penelitian yang dilakukan oleh Pratama (2017) penelitian yang dilakukan adalah Analisis SWOT Sebagai Strategi Pengembangan Objek Wisata Anjungan Tukad Melangit Desa Jehem Kecamatan Tembuku Kabupaten Bangli Tahun 2017. Dari hasil penelitian ini menunjukkan bahwa lingkungan internal perusahaan memiliki posisi yang kuat di mana kekuatan memiliki nilai total sebesar 2,05 berbanding kelemahan sebesar 0,60. Posisi terhadap perusahaan lingkungan juga memiliki posisi yang kuat di mana peluang perusahaan memiliki nilai total sebesar 2,70 berbanding ancaman sebesar 0,60. Dilihat dari nilai total di mana kekuatan sebesar 2,05 dan peluang 2,70 yaitu keunggulan internal dengan peluang lingkungan eksternal berada pada kuadran I (satu), berdasarkan kuadran SWOT maka pilihan alternatif strategi yang bisa di ambil adalah mendukung kebijakan pertumbuhan yang agresif (growth oriented strategy).

\section{SIMPULAN DAN SARAN Simpulan}

Berdasarkan hasil penelitian dan pembahasan di atas, maka dapat disimpulkan bahwa, faktor yang menjadi kekuatan (strengths) dalam mempengaruhi wilayah terdampak erupsi Gunung Agung pada masyarakat di Kecamatan Kubu adalah sisa-sisa aktivitas erupsi dapat menghasilkan bahan-bahan tambang yang berguna dan bernilai tinggi, seperti pasir, kerikil, batubatu besar, semuanya merupakan material industri yang masih diminati oleh konsumen yang dapat digunakan untuk bahan bangunan, kelemahan (weaknesses) wilayah terdampak erupsi Gunung Agung pada masyarakat di Kecamatan Kubu adalah akibat terjadi erupsi Gunung Agung menyebabkan lingkungan sekitar menjadi tercemar, menyebabkan kebakaran hutan, gagal panen, terhentinya industri pariwisata, terhentinya aktivitas mata pencaharian warga sekitar, peluang (opportunities) wilayah terdampak erupsi Gunung Agung 
pada masyarakat di Kecamatan Kubu adalah dengan adanya pertambangan galian C secara tidak langsung dapat memberikan lapangan pekerjaan bagi masyarakat di sekitar galian $\mathrm{C}$ dan dapat mengurangi pengangguran, pendapatan untuk penggali galian $C$ meningkat sehingga membantu perekonomian warga, ancaman (threats) wilayah terdampak erupsi Gunung Agung pada masyarakat di Kecamatan Kubu adalah jika terjadi erupsi Gunung Agung yang cukup besar dan mengeluarkan lava panas maupun lava dingin yang mengaliri sungai dan arus tersebut tidak kuat menampung aliran lava maka akan berakibat pada masyarakat di sekitar karena aliran lava bisa saja mengaliri pemukiman warga sekitar, strategi yang tepat untuk diterapkan pada masyarakat di wilayah terdampak erupsi Gunung Agung adalah strategi pertumbuhan agresif. Salah satu strategi pertumbuhan agresif yang disarankan adalah panetrasi pasar.

\section{Saran}

Berdasarkan simpulan di atas, maka dapat disarankan untuk masyarakat yang tinggal di sekitar Gunung Agung agar dapat memanfaatkan kekuatan dan peluang yang ada untuk dijadikan lapangan pekerjaan dan mempromosikan material-material galian $\mathrm{C}$ sehingga nantinya dapat memberikan pendapatan bagi masyarakat sekitar galian $C$ dan bagi desa setempat. Selain memanfaatkan kekuatan dan peluang yang ada, masyarakat sekitar juga harus memperhatikan dan mengantisipasi segala bentuk kelemahan serta ancaman yang ada akibat dari erupsi Gunung Agung, disarankan kepada perusahaan pertambangan Galian C dalam merekrut tenaga kerja agar mengutamakan warga sekitar Galian C agar dapat mengurangi pengangguran dan menambah pendapatan bagi masyarakat maupun desa setempat. Perusahaan pertambangan Galian C hendaknya lebih mengutamakan mutu, kualitas dan pelayanan untuk menarik minat pembeli, sehingga pembeli berminat untuk datang kembali ke perusahaan dan membeli material-material yang ada di perusahaan.
DAFTAR PUSTAKA

Assauri, Sofjan. 2013. Strategic Management Sustainable Competitive Advantages. Jakarta: Rajawali Pers.

Ghony, Djunaidi dan Fauzan Almanshur. 2012. Metode Penelitian Kualitatif. Yogyakarta: Ar-Ruzz Media.

Marimin. 2004. Teknik Dan Aplikasi Pengambilan Keputusan Kriteria Majemuk. Bogor: Grasindo.

Moleong, Lexy. 2007. Metode Penelitian Kualitatif. Bandung: PT Remaja Rosda Karya.

Narbuko, Cholid dan Abu A Chamadi. 2010. Metode Penelitian. Jakarta: PT Bumi Aksara.

Pratama, I Wayan Edi Yoga. 2017. Analisis SWOT Sebagai Strategi Pengembangan Objek Wisata Anjungan Tukad Melangit Desa Jehem Kecamatan Tembuku Kabupaten Bangli Tahun 2017. Jurusan Pendidikan Ekonomi, Fakultas Ekonomi, Universitas Pendidikan Ganesha.

Rangkuti, Freddy. 2006. Analisis SWOT Teknik Membedah Kasus Bisnis. Jakarta: PT. Ikrar Mandiriabadi.

—_. 2017. Analisis SWOT Teknik Membedah Kasus Bisnis. Cetakan ke-23. Jakarta: PT. Gramedia Pustaka Utama.

Samanlangi, Andi Ilham. 2016. Sistem Penambangan. Yogyakarta: CV Andi Offset.

Sukandarrumidi. 2017. Bahan Galian Industri. Yogyakarta: Gajah Mada University Press.

Sumarni, Murti dan Wahyuni Salamah. 2006. Metodelogi Penelitian Bisnis. Yogyakarta: ANDI.

Sunarto. 2007. Sistem Pengendalian Manajemen. Yogyakarta: Amuss.

Wijaya, Tony. 2013. Metodelogi Penelitian Ekonomi Dan Bisnis. Yogyakarta: Graha IImu. 